\title{
The Relationship between Employee Commitment and Job Attitude and Its Effect on Service Quality in the Tourism Industry
}

\author{
Chung-Chieh Lee, Chih-Jen Chen
}

${ }^{1}$ Department of Senior Citizen Service Management, Chia Nan University of Pharmacy \& Science, Tainan City, Chinese Taipei;

${ }^{2}$ College of Liberal Education, Shu-Te University, Kaohsiung City, Chinese Taipei.

Email: supralee@hotmail

Received December $4^{\text {th }}, 2012$; revised January $18^{\text {th }}, 2013$; accepted February $18^{\text {th }}, 2013$

Copyright (C) 2013 Chung-Chieh Lee, Chih-Jen Chen. This is an open access article distributed under the Creative Commons Attribution License, which permits unrestricted use, distribution, and reproduction in any medium, provided the original work is properly cited.

\begin{abstract}
The main aim of this study was to analyze the relationship between employee commitment and job attitude in the tourism industry and its effect on service quality. This research study attempts to explain the various theories related to employee commitment and job attitude. Primary data for the study was obtained through questionnaires, using structured questions to explain the main objective. The study used a cross-sectional research design to meet the objectives. The data were analyzed using various statistical techniques: SPSS, ANOVA, regression, and correlation analysis. The study found that biographical characteristics of the employees have an effect on job attitude and job commitment. In order to enhance job satisfaction, employees need to be motivated in a relevant manner.
\end{abstract}

Keywords: Employee Commitment; Job Attitude; Service Quality; Job Satisfaction

\section{Introduction}

In recent years, various research articles have focused mainly on employee commitment and attitudes to work in order to enhance the quality of their service delivery or job performance. Research has shown a negative correlation between commitment to work and the satisfaction employees derive from their jobs (Gaertner, [1]). Various factors have been used to analyze this negative relationship, including employee sluggishness in reporting to work, the level of employee absenteeism, and the way employees are remunerated for their work (Gonzalez \& Garazo, [2], p. 42). The chances that employees will remain committed to the organization rely mainly on their level of productivity and the organization's commitment to support them.

Employees' work performance can be analyzed by gauging the level of their commitment and the level of satisfaction that they derive from doing the job. Employee commitment has been defined in numerous ways. Many studies have established relationships between work commitment and attitude and behaviours in the workplace (Maxwell \& Steele, [3]). Work commitment and attitude is related to the employees' behaviour and their performance efficiency (McClurg, [4]). Employee commitment is multi-dimensional in nature, encompassing workers' loyalty, their willingness to exert more effort on behalf of the organization, adherence to organizational values, and desire to remain in the organization (Meyer \& Allen, [5], p. 72).

Employee commitment and job attitude is nowadays considered one of the most important and controversial elements in human resource management, and employee commitment is linked mostly to work values, work motivation, and work involvement. The problem of employee commitment in relation to full-time and part-time work has not been fully explored and therefore requires detailed study and analysis. This study aims to remedy this lack in the literature by adding some more significant information to the subject.

General issues concerning employee commitment and job satisfaction as a part of job involvement and job effectiveness have been explored previously (Miller, Walker, Drummond, \& Hoboken, [6]). The authors discuss aspects of general management theory and key principles governing hospitality organizations. A thorough analysis 
of the problem, however, requires studying contemporary theories on the question. Current research offers a comprehensive analysis of modern theories on central human resources activities and provides new discussion on workplace wellness and ethics in human resources management.

Employee commitment is highly influenced by the level of motivation, which is essential in evoking a positive employee attitude towards the job. Without motivation, the workers feel short-changed; they feel as if they have nothing much to work for (Morrison \& Robinson, [7]). To define the motivation problem more specifically, Schermerhorn, Hunt, and Osborn [8], among a range of issues, focus on questions concerning ethics, leadership, and the work commitment of employees in the tourism industry. They assert that part-time work is becoming more popular, despite its controversial work arrangements.

Current media coverage on the sluggish growth in the tourism industry has confirmed that employees in the industry have a varied level of commitment and attitudes to their jobs (Morrow, [9]). Some employees have been portrayed as not committed at all to their jobs: they are lazy; they lack a sense of professionalism; they are seen as people who come to work only to receive their salary at the end of every month. If the level of employee performance is to be raised, the organization needs to focus heavily on altering the working environment to raise the level of employee satisfaction. Thus, employees will be enabled to adopt a positive attitude towards their jobs, by which they may become true professionals (Morrison \& Robinson, [7]).

Employee dissatisfaction most often rises from various changes in job policies. Workers are not always consulted when such changes are effected, and often some of their rights are violated. Such situations produce frustration and disappointment, which, in turn, affect employees' level of commitment and productivity. When employees can participate in decisions regarding their job environment, they develop a positive attitude; thus, satisfaction and productivity are both enhanced.

Casual employment has been increasing rapidly over the last two decades, particularly in service sectors like the tourism industry. Many researchers have argued that such employment arrangements can be beneficial for both organizations and workers. However, the comparatively high level of staff turnover in the tourism industry in many countries has resulted to increased costs for the businesses. The most significant factor contributing to this turnover rate is the level of job commitment among the employees of these organizations. This paper explores the relationships between employee commitment, job attitude, and service quality.

\section{Literature Review}

According to Bratton and Gold [10] employee commitment is relative to the workers' attachment to or participation in the organizations in which they employed. Employee commitment is significant since it determines whether employees are likely to leave their jobs or improve performance. Numerous studies have related to employee commitment. Mowday, Steers, and Porter [11] emphasized concepts they referred to as attitudinal commitment and behavioral commitment. Another concept introduced by Meyer and Allen [12] is the most recognized among employee commitment theories. In this approach, employee commitment has three multi-dimensional components namely: affective commitment, continuance commitment, and normative commitment.

Affective commitment, which relates to emotional attachment, is normally linked to a favorable working environment and relationships with the other employees. Normative commitment, on the other hand, is related to obligation: employees may feel they owe the organization for being given a job when they need it most. Finally, continuance commitment relates to such terms of employment as job contracts, which may make leaving the current job very costly or troublesome (Mullins, [13]).

Work performance and turnover owing to organizational environment have become a major headache to many heads of organizations in general, and human resource managers in particular (Freund \& Carmeli, [14]). This problem is mostly attributable to lack of stability and job security for employees, who constitute one of the most important resources in the organization. Many organizations have begun to foster workers' commitment to their work/occupation/career; to the organization, its values, and ambitions; and to a strong job ethic.

\subsection{Models of Employee Commitment}

The soaring rate of rotation typical of the modern organizational environment has called for addressing the challenges and complications resulting from the turnover rate. To address the impasse related to this objective, organizational efforts have progressed in two directions. At the micro level, human resource managers look at worker commitment to a specific occupation and focus on modifying the human resource structure to accommodate employee needs and achieve the operational goals. Achieving a balance between organizational goals and workers' needs requires both a kind of psychological contract and a sound view of the dynamic between trade and stability.

Freund and Carmeli [14] presented a model for five general forms of employee commitment: career, affirmative, work ethic, occupational, and organizational com- 
mitment (which includes both continuance and affective commitment). The above five commitments are further classified into two major groups. The first category centres on commitments that affect work attitudes without reference to the organization: work ethic, career, and occupational. The second category is influenced by the organization in which the employees work: continuance and affective organizational commitment (Furnham, [15]).

In spite of the great significance attributed to the relationship between work positions and work results, only a few studies have explored the link between multiple commitments and work results. Most of these studies deal with solitary variables - for instance, organizational commitment or satisfaction and its relation to the quality of service (Bayazit \& Mannix, [16]). Morrow [9] developed an early model based on the idea of multiple commitments and the relationships between them. Morrow's model covered the five commitments that influence organizational outcomes and arranged them in a logical order. According to Morrow, different forms of commitments have reciprocal influences, which result in a circular structure based on the affirmative work ethic as linked to occupational commitment and continuance commitment. Job attitude is related to effective commitment and continuance commitment. As a result, continuance commitment is connected to affective commitment, and both affect job involvement to complete the circle (Bayazit \& Mannix, [16]).

Further studies using the above model have established that different forms of commitments share elements among themselves. The most fundamental form of commitment, which possesses minimal ability for influence and change, is the affirmative work ethic (Furnham, [15]). This form of commitment, with which the employee is hired into the organization, will remain part of him in his career life with only small changes and with no connection to the various organizations for which the employee has worked. Nonetheless, an affirmative work ethic affects other forms of commitment, such as continuance commitment (Lowry, Simon \& Kimberley, [17]). An affirmative work ethic is associated with occupational commitment because high moral standards will positively influence an individual's persistence in a given job or career. Additionally, an affirmative work ethic influences continuance commitment because the work relationships (which are a type of friendship) established by an employee with an affirmative work ethic arise out of the workplace (Aksu \& Aktas, [18]).

According to Morrow's model, job involvement is influenced mostly by continuance commitment and affective commitment. Job involvement will be influenced by continuance commitment on the assumption that a satis- factory relationship with the organization will persuade the employees to invest more in their jobs (Brotherton, [19]). Affective commitment assumes that employee identification with organizational objectives and values will foster greater investment in the job and will therefore increase employees' involvement.

Job involvement, in turn, is dominated by an affirmative work ethic, which is a long-term and comparatively steady characteristic. Affective, continuance, and occupational commitments, in contrast, are unstable and can change comparatively faster. An affirmative work ethic tends to result in job involvement that, in turn, fosters a high commitment to work, which increases a person's job commitment (Brotherton, [19]). Hence, in Morrow's model, job involvement is straightforwardly connected to organizational results (Bateman \& Strasser, [20]).

Cohen [21] introduced another system of reciprocal influence between the five different forms of commitment. Cohen also used an affirmative work ethic as the basic variable in his model; thus, it becomes the only variable that can hardly be changed in Cohen's model (Conway \& Briner, [22]). An affirmative work ethic is the fundamental influence on other forms of commitment for any employee, yet it has no straightforward relation to the organizational outcome or commitment simply because it takes a very long time to change this variable. Therefore, in this model, an affirmative work ethic can influence only job involvement and not other variables.

Cohen introduced a completely different context regarding the relationships among the different forms of commitment (De Vaus, [23]), although the model uses the same five fundamental commitments described by Morrow [9]. According to Cohen's model, job involvement will influence occupational, affective, and continuance commitments. However, unlike Morrow's model, occupational commitment also influences continuance commitment and affective commitment (De Vaus, [23]). These two forms of commitments are the most subjective and are the most likely to change.

\subsection{Job Attitude, Job Satisfaction and Work Commitment}

Schwepker [24] defined job satisfaction as "the pleasurable emotional state resulting from the appraisal of one's job as achieving or facilitating one's values". At the same time, he defined job dissatisfaction as "the unpleasant emotional state resulting from the appraisal of one's job as frustrating or blocking the attainment of one's values". Herzberg, Mausner, and Snyderman [25] presented a famous theory of job satisfaction and job attitude. The two-factor theory posits that workers have primarily two kinds of needs - namely, motivation and hygiene. Hygiene factors are those necessities that can be 
satisfied by particular conditions, such as regulations, interpersonal relations, working conditions, and remunerations. The theory suggests that job dissatisfaction normally arises in cases where hygienic factors do not exist. The supply of hygiene needs, however, does not necessarily translate to full satisfaction. Rather, it tends to minimize the level of dissatisfaction (Huczynski \& Buchanan, [26]).

On the Minnesota Satisfaction Questionnaire (MSQ), job satisfaction is presented as an attitude comprising three factors: extrinsic, intrinsic, and overall corroboration factors. Intrinsic factors include ability utilization, independence, ethical values, responsibility, security, ingenuity, societal services, societal status, and diversity. On the other hand, extrinsic factors include expansion, organizational policy, compensation, acknowledgment, and supervision of human capital (Schwepker, [24]).

Many researchers have treated work commitment and job satisfaction as an independent variable that can be viewed from different angles (Jernigan, Beggs \& Kohut, [27]. Job satisfaction is a form of reaction to a particular job or work-related subject, whereas commitment is more of a universal response. For that reason, commitment should be more consistent than job satisfaction in an organization (Feinstein \& Vondrasek, [28]). In their study of tourism employees, Feinstein and Vondrasek established that the level of satisfaction predicts organizational commitment. Another study conducted by Gaertner [1] on the determinants of job satisfaction and organizational commitment established that job satisfaction is the basis of organizational commitment.

Jernigan et al. [27] explored the role that particular determinants of job satisfaction play in predicting different types of commitment in an organization. They established that effective commitment differs according to an individual's satisfaction with the work context. In such cases, the role of the management cannot be overlooked because managers are the key people with the highest level of responsibility for moving the organization ahead. Research conducted by Maxwell and Steele [3] among hotel managers identified principles that enhance the level of commitment in organizations. These include high and equitable remuneration, employers' interest on their workers, a high level of cooperation in the organization, and opportunities to take part in social activities (Maxwell \& Steele, [3]).

According to Maxwell and Steele [3], payment strategy and recognition are extrinsic job satisfaction variables, whereas workers' interest in terms of autonomy, security, teamwork and trust in terms of moral values, and opportunities to take part in social activities are intrinsic job satisfaction variables. On the other hand, Bateman and Strasser [20] posit that employee commit- ment can sometimes be an independent variable with job satisfaction as the resultant variable. They argued that employees who are highly committed to an organization may experience a high level of satisfaction in their work. According to Lam, Pine, and Baum [29], highly committed employees will endeavour to meet an organization's goals and interests. This kind of attitude will influence the budgetary planning and goals of the managers. Thus, satisfaction is proposed as an outcome instead of an antecedent. In general, the theory suggests that job satisfaction is a precursor of organizational commitment wherein the aspect of job satisfaction has a strong impact on the dimension of organizational commitment (Lam et al., [29]).

In the United States, McClurg [4] carried out an investigation on whether patterns of employee commitment from normal work settings are applicable in the temporary-help service sector. She recommended that offering support to part-time workers in a non-monitory manner is the most effective way of enhancing organizational commitment. McClurg also noted that part-time employees should be considered as a homogeneous group because there are numerous reasons for hiring them and treating them differently; such treatment may affect their commitment to work.

Lowry et al. [17] established that part-time employees encounter varying levels of work commitment and job satisfaction in relation to their perception of work context aspects-for instance, training, promotion, scheduling of work, organizational practices, and interpersonal relationships. They asserted that satisfaction with employment security has less effect on work commitment than does satisfaction with quality of life. Brotherton [19] established that, from the perspective of nurturing commitment and innovation among hotel workers, the most significant thing is clarity in the employment contract, rather than whether or not the contract offers a level of permanency or job security to the workers. He also found out that, in a number of situations where the job contract was as specific as possible regarding job requirements, some employees performed better than other employees whose psychological contract entailed broader expectations - for instance, corporate citizenship.

Employee commitment is beneficial to both employers and employees (Clarke \& Chen, [30]). For individual employees, work commitment signifies a positive relationship with the organization and attaches more meaning to life, whereas for employers, committed workers are likely to enhance the service, reduce turnover, and reduce cases of absenteeism (Chon, Sung, \& Yu, [31]). Organizational commitment has also been associated with efficiency, productivity, creativity, and innovativeness among employees (Lashley \& Lee-Ross, [32]). 
Allen and Meyer [33] are among the authors who have linked work commitment and staff turnover. According to them, highly committed workers are less likely to quit the organization. They relate turnover intention to affective commitment and to a slighter degree, normative commitment. The link between continuous commitment and staff turnover intention is not consistent across studies, however (Chon, Sung \& Yu [31]). The same is true regarding the measurement of actual turnover, taking into consideration only affective and normative commitment, not continuance commitment (Schermerhorn, Hunt \& Osborn, [8]).

Numerous approaches have been developed to assess organizational commitment (Mullins, [13]). The most widely accepted approach is the use of Organizational Commitment Scale (OCS), developed by Allen and Meyer [33]. OCS measures the three forms of commitment (affective, continuance, and normative). OCS has been widely used in a broad range of samples and situations and has been significantly reviewed by numerous researchers (Allen \& Meyer, [33]).

\subsection{Job Satisfaction and Work Commitment in the Tourism Industry}

A study conducted by Aksu and Aktas [18] regarding the job satisfaction of managers in a five-star hotel established that improved working conditions can enhance job satisfaction. Improved working conditions in this case encompassed work promotions, boosting employee morale, financial rewards, fringe benefits and compensation, and realistic working hours. Lam et al. [29] suggested that training and development can assist in enhancing job satisfaction in the service industry. The study also found out that managers in the tourism industry play a significant role in work commitment and satisfaction. The study established that seniors or mentors in the tourism industry are likely to encourage their juniors or the newcomers, thus influencing their job satisfaction and behavioural intent (Lam et al., [29]).

Jernigan et al. [27] studied the relationship between workers' service orientation and job satisfaction, organizational commitment, and intention to quit the job. The study, which covered restaurant workers, found that consumer emphasis on the service of the employees is negatively correlated with job satisfaction but positively correlated with organizational commitment; support from the organization is positively correlated with job satisfaction; and organizational commitment is negatively correlated with workers' intention to quit their jobs (Jernigan et al., [27]).

Lowry et al. [17] conducted a study on the effects of executives' personal characteristics - such as competiveness, endeavour, and individual efficacy - on frontline workers' performance and job satisfaction. They suggested that if executives are committed to service delivery, they should promote their employees' jobs as careers instead of merely jobs and should attract competitive and individual efficacious staff. In addition, they should promote a sound environment in order to reduce the chances of conflict arising from unhealthy competition. Another study among the frontline staff found out that employees' satisfaction is based on personal values in addition to organizational factors. Satisfied workers are more likely to satisfy the clients, thus helping the organization to move forward.

Bratton and Gold [10] recommended that managers focus more on frontline staff to arouse job satisfaction and organizational commitment/citizenship because service communicative management services promote organizational commitment and enhance job satisfaction among employees. Finally, Elizur et al. [34], in studying food service workers and their managers, found out that remuneration, fringe benefits, working hours, welfare services, and family all influence job attitudes in the hotel industry. The study also established that low-ranking employees were more likely to quit than those of higher rank.

\subsection{Work Values and Commitment}

There has been a growing interest in the study of human values and work values over the recent years. Most of these studies have emphasized typology and quantification of values over dynamic priorities - for instance, stability and change, and the relationships among values and attitudes, objectives, and character (Redman \& Wilkinson, [35]). Some authors have tried to distinguish values from attitudes, whereas others have tried to relate them. According to Elizur et al. [34], work values are defined as a conglomeration of attitudes and opinions with which employees can assess their jobs and work surroundings. Hertberg, Mausner, and Snyderman [25] regarded work values as representing motivational aspects. On the other hand, Bratton and Gold [10] considered that work values represent an affirmative work ethic.

A number of studies have regarded values and work values in particular as a significant variable in describing organizational commitment (Conway \& Briner, [22]). According to Feinstein and Vondrasek [28], commitment is an expression of one's own self, mirroring standard values that are fundamental to one's existence as a person. Elizur et al. [34], however, established a restrained relationship between work values and employee commitment. Miller et al. [6] studied the relationship between the work values and organizational commitment of workers in the tourism industry. They established that 
intrinsic work values were closely more related to organizational commitment in comparison to extrinsic work values.

\subsection{Work Commitment among Employees}

In contemporary society, the employment relationship has remarkably changed. Workers' job status has now developed into two types: standard work status (permanent or full-time) and non-standard work status (temporary, contractual, or part-time). Most organizations have turned to non-standard work status to provide a high level of scheduling flexibility, meet unexpected demand more efficiently, and cut down on the cost of wages and salaries. In addition, the number of part-time employees is the highest in the service industry (Conway \& Briner, [22]).

In spite of the growing significance of this category of workers in different sectors of the economy, comparatively little research has been done on part-time employment. Part-time employees are known to differ in numbers from full-time workers, but the degree to which their work attitudes differ is less apparent (Krausz, Sagie $\&$ Bidermann, [36]). Many studies on part-time and fulltime employees have concentrated on the differences in the attitudes and behaviours of these two categories of workers. However, a number of studies have touched on work status, work commitment, and job satisfaction. Other studies have even considered further relationships-for example, work status and organizational environment.

Studies evaluating job satisfaction across full-time and part-time workers exhibit contradictory results. Studies have found that part-time as compared to full-time workers are more, less, and equally satisfied with their work (Krausz et al., [36]; Sinclair, Martin, \& Michel, [37]). Correspondingly, contradictory results have also emerged from comparing the commitment levels of the two sets of employees. These studies have also found that, compared to full-time workers, part-time workers are more, less, and equally committed to their work (Krausz et al., [36]; Martin \& Hafer, [38]; Sinclair et al., [37]). Researchers who have attempted to explain these disparities have usually applied the theories of partial inclusion and frame of reference (Krausz et al., [36]).

Using the theory of partial inclusion, some researchers argue that part-time workers are partially included because they spend fewer hours in the workplace and are more involved in organizational operations than are fulltime workers (Conway \& Briner, [22]). According to frame theory, part-time workers are believed to have frames of reference that differ from those of full-time employees, given that the groups and aspects of work environment chosen for analyzing the two job categories always differ. For instance, some studies have found that flexibility of working hours is more important to parttime employees than to full-time workers.

The two theories have also been used paradoxically in many ways to explain the difference between the two types of work status. For example, researchers have used the feeling of inclusivity to explain higher levels of job satisfaction. In actuality, the partial inclusion and frame of reference theories can be manipulated to describe any empirical results since they are normally used to post rationalize results (Conway \& Briner, [22]). However, none of these theories has been tried experimentally, and because they are scantily described, it is not apparent how they may be put into practice.

Psychological contract theory has also been used as a descriptive framework for the employment relationship and for explaining workers' attitudes and behaviours (Sinclair et al., [37]). This theory has been used in many ways to describe employment relationship, but the main construct shows organizational results to be achieved through psychological contract achievement or contravention. A positive correlation has been found between psychological contract realization and job satisfaction, organizational commitment, and performance. It has also found to be negatively correlated to an intention to quit the organization

Therefore, psychological contract theory is a very reasonable approach to understanding the attitudes and behaviours of workers in different types of employment, including contingency employment (Sinclair et al., [37]).

At the organizational level, it has been found that part-time employees are treated differently from full-time employees regarding tasks performed, remuneration, work diversity, independence, and opportunities to grow. For instance, some evidence shows that part-time employees are unlikely to be given the same promotion and training opportunities in the same organization (Lam et al., [29]). Part-time employees are normally hired when an organization is experiencing busy periods, and they are expected to perform fairly repetitive tasks during these periods. As a result, part-time employees' contributions are perceived as dissimilar from those of full-timers in terms of effort and flexibility.

At a personal level, part-timers have different professional orientations; thus, they may trade off types of compensation for greater flexibility and extra time to attend to other commitments (Lam et al., [29]). Many researchers have predicted that full-timers have much greater expectations than part-timers regarding what they should get from the organization (Sinclair et al., [37]). At an interpersonal level, part-time employees in many cases are treated differently or subjected to different assumptions by the leadership and fellow employees. 
Studies have established that part-time employees are managed mostly under the assumptions of theory $\mathrm{X}$ and of stereotypes. Part-timers may see different treatment according to work status as interactional prejudice (Morrison \& Robinson, [7]).

\section{Research Methodology}

\subsection{Research Philosophy, Design, and Statistical Methods}

For analyzing the relationship between employee commitment and job attitude and its effect on service quality, the philosophy of the research design would need to be either positivist or social constructionist (Easterby, Thorp \& Lowe, [39]). Social constructionism was chosen as the better perspective for this project because reality is regarded as a one-sided phenomenon that can be constructed socially to uncover new significance. The focus is on meaning as the researcher looks for understanding about what really happened and develops ideas from the data.

In line with the main objective of this study, a crosssectional research design was employed. Descriptive statistics and inferential statistics were both applied in the study in order to test the hypotheses

\subsection{Sample Selection}

For this study, a non-probability sampling design was used. The respondents, 450 in number, were targeted and given questionnaires to assist with data collection. The respondents were assured of the confidentiality of their participation.

\subsection{Data Collection and Instrumentation}

Questionnaires were used to collect the data. The questionnaires were issued to 450 respondents who were mainly employees in the tourism industry. Correct confidentiality procedures were observed.

\subsection{Limitation of Data Collection Methods}

There have been a lot of concerns on additional budgetary expenses for collection of the data, regardless of whether the gathered data is really genuine or not and whether there may be an explicit conclusion when interpreting and analyzing the data. In addition, some employees were reluctant to offer some information they deemed confidential and unsafe in the hands of their competitors. This posed a great challenge to the research as the researcher had to take a longer time to find employees who were willing to give out adequate information.

\section{Findings, Data Analysis, and Interpretation}

This section covers the analysis of the data, presentation, and interpretation. The descriptive statistics presented in Section 4.1 were derived from the questionnaires. The results were analyzed using SPPS, ANOVA, regression, and correlation analysis.

\subsection{Descriptive Statistics}

\section{Biographical Information}

Out of 450 participants chosen, 237 (52.6\%) responded by completing the questionnaires. The age distribution of the respondents is summarized in Figure 1(a).

The figure indicates that the largest group of respondents, the $40-49$ year age group, made up $43 \%$, followed by respondents in the $30-39$ age group at $24 \%$. The 50 - 59 age group came in at $23 \%$, with the under 30 group making up the smallest portion of respondents at $10 \%$.

The gender distribution of the respondents is summarized in Figure 1(b), and it shows that $60 \%$ of the respondents were female, whereas only $40 \%$ were male employees.

Figure 1(c) summarizes the race distribution of the employees. It shows that $53 \%$ - a majority of the employees were coloured. This category was followed by Blacks at $18 \%$ and Whites at $16 \%$, with Asian employees constituting the lowest portion at $13 \%$.

Figure 1(d) shows the results of the analysis of employee qualifications. The figure demonstrates that $54 \%$ of the employees possessed bachelor's degrees. Higher diploma holders came in at $18 \%$ and diploma holders at $16 \%$, with master's degree holders constituting the smallest portion at $12 \%$.

The employment category distribution is summarized in Figure 1(e). The figure shows that $55 \%$ of the respondents, a majority, were employed on a permanent basis. Temporary employees made up $37 \%$, and only $8 \%$ of the respondents were employed on contract.

\subsection{Summary of Results from Descriptive Statistics}

\subsubsection{Results for Job Attitude}

The questionnaire itself focused mainly on employee commitment and job attitude. The summary of results regarding job attitude is summarized in Table A1. The results show that from the sample of 237 respondents, the mean for job attitude is 113.20 with a standard deviation (SD) of 14.30. This computation demonstrates that many employees still have a less-than-optimal attitude to their jobs, as indicated by the lower value of the standard deviation. A low score on job attitude indicates that the 


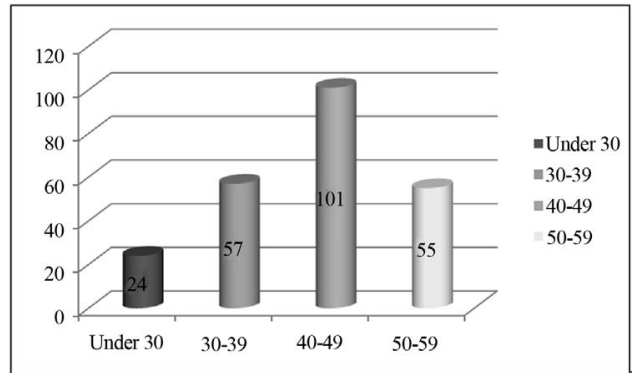

(a)

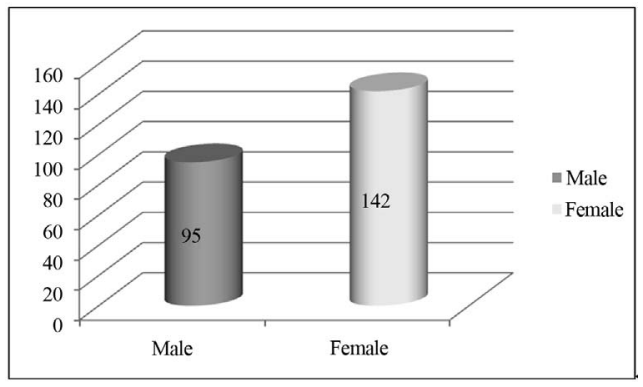

(b)

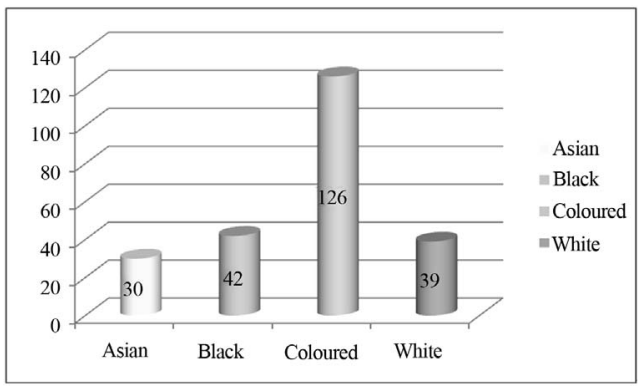

(c)

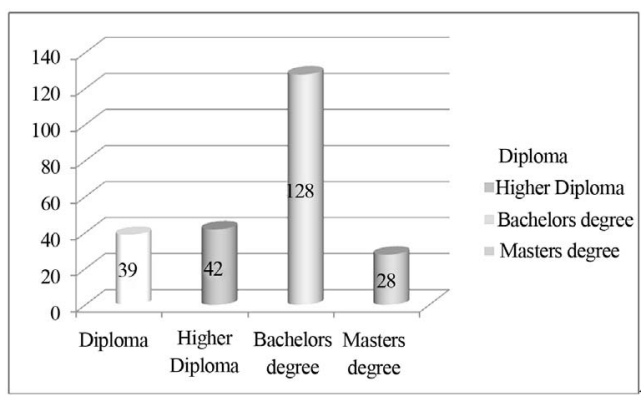

(d)

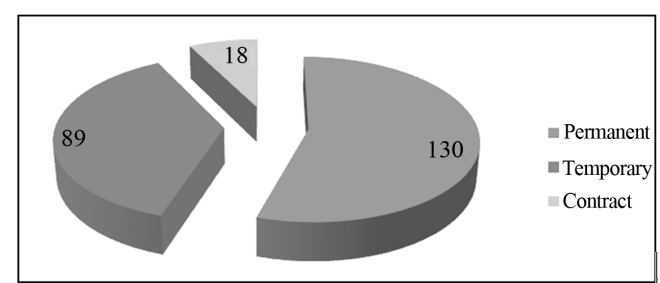

(e)

Figure 1. (a) Age distribution; (b) Gender distribution; (c) Race distribution; (d) Employee quality distribution; (e) Employment category distribution. level of satisfaction is also low. In addition, the calculated arithmetic means for job environment, remuneration, administration, and job progress are less than the calculated arithmetic mean for work colleagues. Since the average level of satisfaction is represented by a mean of 36 , it is evident that many employees have a low score for job attitude because they are not satisfied with the job environment, remuneration, administration, and job progress. Employees were greatly satisfied by their colleagues (mean $=38.24, \mathrm{SD}=3.13$ ) than the job environment $($ mean $=32.12, \mathrm{SD}=6.30)$, administration $($ mean $=$ $27.20, \mathrm{SD}=5.30)$, job progress $($ mean $=24.35, \mathrm{SD}=$ 4.22 ) and remunerations (mean $=23.10, \mathrm{SD}=4.80)$.

\subsubsection{Results for Employee Commitment}

The summary of results regarding employee commitment, which is shown in Table A2, shows that the total organizational commitment has a mean of 55.43 and a standard deviation of 9.24. Since the average level of employee attitude is represented by a mean of 60 , it is evident that a large number of employees portrayed a below-average level of organizational commitment. In addition, affective commitment (mean $=20.12, \mathrm{SD}=$ 3.02) stipulates that the employees do not have a high level of faith in the values and beliefs of the organization. The normative commitment level $($ mean $=22.41, \mathrm{SD}=$ 5.02) demonstrates that employees are reluctant to represent the organization in transacting business. Continuance commitment (mean $=17.02, \mathrm{SD}=7.41$ ) shows that employees are uncertain about continuing to work for the organization.

\subsection{Inferential Statistics}

The results of inferential statistics were used to establish the relationship that exists between job commitment and job attitude among employees; in addition, inferential statistics were used to ascertain the connection between employee commitment, job attitude and provision of quality service. The results are summarized in the Tables A3-A8.

The results in Table A3 show major correlations between remuneration and job attitude $(\mathrm{r}=0.598, \mathrm{p}<0.01)$, job progress and job attitude $(\mathrm{r}=0.585, \mathrm{p}<0.01)$, work colleagues and job attitude $(r=0.386, p<0.01)$ and administration and job attitude $(r=0.268, \mathrm{p}<0.05)$. There was no significant relationship between the nature of the job and job satisfaction $(r=0.113, p>0.05)$.

The Table A4 results confirm that the most significant relationship occurs between sex and job attitude $(r=$ $0.67, p<0.01$ ). In addition, the age of respondents and job attitude were strongly correlated $(\mathrm{r}=0.50, \mathrm{p}<0.01)$. There was also a significant relationship between job status and job attitude $(r=0.45, p<0.01)$, and job level 
and job attitude $(r=0.37, p<0.01)$. Finally, there was a strong relationship between education and job attitude $(\mathrm{r}=$ $0.28, \mathrm{p}<0.05$ ).

The results in Table A5 show a slight relationship between affective commitment and job attitude $(\mathrm{r}=0.342$, $\mathrm{p}<0.01)$ and a strong relationship between normative commitment and job attitude $(r=0.436, p<0.01)$. Furthermore, there was a strong relationship between continuance commitment and job attitude $(\mathrm{r}=0.701, \mathrm{p}<$ 0.01 ). There was also a significant relationship between organizational commitment and job attitude $(r=0.434, p<$ $0.01)$.

The Table A6 results show a significant relationship between sex and employee commitment $(r=0.702, p<$ 0.01 ) and between the age of respondents and employee commitment $(\mathrm{r}=0.560, \mathrm{p}<0.01)$. A strong relationship exists between job status and employee commitment $(\mathrm{r}=$ $0.420, \mathrm{p}<0.01)$ and between job level and employee commitment $(\mathrm{r}=0.552, \mathrm{p}<0.01)$. However, no signifIcant relationship was found between the educational level of employees and their job commitment $(r=0.132$, $\mathrm{p}>0.05$ ).

Table A7 reveals the biographical variables regressed against job attitude, and Table A8 shows the ANOVA Analysis. The result showed the multiple R-value to be 0.602 . The R-Square value of 0.361 indicates that $36.1 \%$ of the variables explained the dependent variable. The F-statistic (5.295) is statistically significant at the 0.01 level, meaning that the demographic variables significantly enlighten $36.1 \%$ of the variance in job attitude. Job status is the best predictor of job attitude because it has a beta coefficient value of -0.3189 and is statistically significant at the 0.01 level. In addition, sex, age, and job level are statistically significant at 0.05 . The negative value of the beta coefficient of job level indicates that employees in higher positions of employment have a less positive attitude towards their jobs. In the same manner, the negative beta value of the age coefficient shows that older employees have a less positive attitude towards their jobs.

The results of Table A9 are for the biographical variables regressed against employee commitment. Table A10 shows the ANOVA Analysis. The result showed a multiple R-value of 0.622 . The R-Square value of 0.390 indicates that $39 \%$ of the variables explained the dependent variable. The F-statistic (5.357) is statistically significant at the 0.01 level; meaning that the demographic variables shed significant light on $39 \%$ of the variance in employee commitment.

Furthermore, job status had the highest beta-value, followed by sex, age, and job level; all these variables statistically explain the variance in employee commitment. The negative beta value for job status indicates that employees who have been in the organization for long are less committed.

\section{Summary of the Findings, Conclusions, and Recommendations}

\subsection{Summary of Findings}

The main objectives of this study were to investigate the relationship between employee commitment and job attitude and its effect on service quality in the tourism industry. The objectives were satisfied by collecting and analyzing pertinent data using various statistical techniques. In line with the objectives, the following hypotheses were tested: biographical factors do not affect the level of employees' commitment and job attitude in an organization; job motivation and satisfaction have no impact on employee commitment and job attitude; there is no relationship between job commitment and job attitude among employees; and there is no connection among job attitude, job commitment, and provision of quality service. The study established that biographical factors do have an impact on both employee commitment and job attitude. The study also established a relationship between job attitude and employee commitment towards the delivery of quality service.

\subsection{Conclusions}

Job attitude and employee commitment are the basis for delivering quality service. The study established that biographical characteristics of the employees in terms of age, gender, job level, education level, and job status have an effect on job attitude and the employee commitment to work. The study established that in many cases, employees who have stayed longer in the job develop a more negative attitude towards their jobs, which affects their commitment to their work. Older employees also tend to assume a more negative job attitude because of many years of working in the same organization at the same level.

The study has revealed that motivation is the key to employees' success in the workplace. The more motivation employees have, the more committed they become to the organization. Thus, motivation is necessary for fostering a good job attitude in the workers. An organization which does not motivate its employees is bound to lag behind in terms of competition in the market. Many potential employees are attracted by the motivating elements that exist in a company, and motivation helps to retain the existing good workers that the organization has.

\subsection{Recommendations}

Based on the findings of this study, there is a need to motivate employees to improve their work commitment 
and job attitude. In order for an organization to be successful, the needs of both the organization and the employees must be satisfied; the management should establish a cohesive relationship with the employees to achieve forward momentum. Employees have a role to play by adhering to the rules and regulations of the organization. On the other hand, employees anticipate favourable working conditions in terms of good salary, good treatment, job security, and enough attention from the managers. Both the organization and employees have expectations over and above the black-and-white terms of the employment contract. The needs and anticipations of both the employers and the employees differ from one organization to another. It is, therefore, of the essence for the organization to anticipate employees' desires so as to come up with a better way to motivate them.

\section{REFERENCES}

[1] S. Gaertner, "Structural Determinants of Job Satisfaction and Organizational Commitment in Turnover Models," Human Resource Management Review, Vol. 9, No. 4, 1999, pp. 479-493. doi:10.1016/S1053-4822(99)00030-3

[2] J. V. Gonzalez and T. G. Garazo, "Structural Relationships between Organizational Service Orientation, Contact Employee Job Satisfaction and Citizenship Behavior," International Journal of Service Industry Management, Vol. 17, No. 1, 2006, pp. 23-50. doi:10.1108/09564230610651561

[3] G. Maxwell and G. Steele, "Organizational Commitment: A Study of Managers in Hotels," International Journal of Contemporary Hospitality Management, Vol. 15, No. 7, 2008, pp. 362-369. doi:10.1108/09596110310496006

[4] L. N. McClurg, "Organizational Commitment in the Temporary-Help Service Industry," Journal of Applied Management Studies, Vol. 8, No. 1, 1999, pp. 5-26.

[5] J. P. Meyer and N. J. Allen, "Commitment in the Workplace: Theory, Research, and Application," Sage, Thousand Oaks, 1997.

[6] J. E. Miller, K. E. Walker, K. E. Drummond and M. Hoboken, "Supervision in the Hospitality Industry," 4th Edition, John Wiley \& Sons, Hoboken, 2002.

[7] E. W. Morrison and S. L. Robinson, "When Employees Feel Betrayed: A Model of How Psychological Contract Violation Develops," Academy of Management Review, Vol. 22, No. 1, 1997, pp. 226-256. doi:10.5465/AMR.1997.9707180265

[8] J. R. Schermerhorn, J. G. Hunt and R. N. Osborn, "Organizational Behavior," 8th Edition, John Wiley \& Sons, Hoboken, 2003.

[9] P. C. Morrow, "The Theory and Measurement of Work Commitment," JAI Press, Greenwich, 1993.

[10] J. Bratton and J. Gold, "Human Resource Management: Theory and Practice," 4th Edition, Palgrave Macmillan, Basingstoke, 2007.

[11] R. T. Mowday, R. M. Steers and L. W. Porter, "The
Measurement of Organizational Commitment," Journal of Vocational Behavior, Vol. 14, No. 2, 1979, pp. 224-247. doi:10.1016/0001-8791(79)90072-1

[12] J. P. Meyer and N. J. Allen, "A Three-Component Conceptualization of Organizational Commitment," Human Resource Management Review, Vol. 1, No. 1, 1991, pp. 61-89. doi:10.1016/1053-4822(91)90011-Z

[13] L. J. Mullins, "Hospitality Management and Organisational Behavior," 4th Edition, Pearson/Longman, Harlow, 2001.

[14] A. Freund and A. Carmeli, "An Empirical Assessment: Reconstruct Model for Five Universal Forms of Work Commitment," Journal of Managerial Psychology, Vol. 18, No. 7, 2003, pp. 708-725. doi:10.1108/02683940310502403

[15] A. Furnham, "The Protestant Work Ethic, the Psychology of Work-Related Beliefs and Behaviors," Routledge, London, 1990.

[16] M. Bayazit and E. A. Mannix, "Should I Stay or Should I Go? Predicting Team Members' Intent to Remain in the Team," Small Group Research, Vol. 34, No. 3, 2003, pp. 290-321. doi:10.1177/1046496403034003002

[17] D. S. Lowry, A. Simon and N. Kimberley, "Toward Improved Employment Relations Practices of Casual Employees in the New South Wales Registered Clubs Industry," Human Resource Development Quarterly, Vol. 13, No. 1, 2002, pp. 53-70. doi: $10.1002 / \mathrm{hrdq} .1013$

[18] A. Aksu and A. Aktas, "Job Satisfaction of Managers in Tourism: Cases in the Antalya Region of Turkey," Managerial Auditing Journal, Vol. 20, No. 5, 2005, pp. 479488. doi:10.1108/02686900510598830

[19] B. Brotherton, "International Hospitality Industry: Structure, Characteristics and Issues," Butterworth-Heinemann, New York, 2003.

[20] T. Bateman and S. Strasser, "A Longitudinal Analysis of the Antecedents of Organizational Commitment," Academy of Management Journal, Vol. 27, No. 1, 1984, pp. 95-112. doi: $10.2307 / 255959$

[21] A. Cohen, "Relationships among Five Forms of Commitment: An Empirical Assessment," Journal of Organizational Behavior, Vol. 20, No. 3, 1999, pp. 285-308. doi:10.1002/(SICI)1099-1379(199905)20:3<285::AID-JO B887>3.0.CO;2-R

[22] N. Conway and R. B. Briner, "Full-Time versus PartTime Employees: Understanding the Links between Work Status, the Psychological Contract, and Attitudes," Journal of Vocational Behavior, Vol. 61, No. 2, 2002, pp. 279-301. doi:10.1006/jvbe.2001.1857

[23] D. De Vaus, "Research Design in Social Research," Sage, London, 2001.

[24] C. H. Schwepker, "Ethical Climate's Relationship to Job Satisfaction, Organizational Commitment, and Turnover Intention in the Sales Force," Journal of Business Research, Vol. 54, 2001, pp. 39-52. doi:10.1016/S0148-2963(00)00125-9

[25] F. Herzberg, B. Mausner and B. Snyderman, "The Moti- 
vation to Work," Wiley, New York, 1959.

[26] A. Huczynski and D. Buchanan, "Organizational Behavior: An Introductory Text," 6th Edition, Pearson/Prentice Hall, Harlow, 2007.

[27] I. E. Jernigan, J. M. Beggs and G. F. Kohut, "Dimensions of Work Satisfaction as Predictors of Commitment Type," Journal of Managerial Psychology, Vol. 17, No. 7, 2002, pp. 564-579. doi:10.1108/02683940210444030

[28] A. H. Feinstein and D. Vondrasek, "A Study of Relationships between Job Satisfaction and Organizational Commitment among Restaurant Employees," Journal of Hospitality, Tourism, and Leisure Science, Vol. 1, No. 4, 2001, pp. 1-20.

[29] T. Lam, R. Pine and T. Baum, "Subjective Norms: Effectives on Job Satisfaction," Annals of Tourism Research, Vol. 30, No. 1, 2003, pp. 160-177. doi:10.1016/S0160-7383(02)00047-6

[30] A. Clarke and W. Chen, "International Hospitality Management: Concepts and Cases," Taylor \& Francis, New York, 2007.

[31] K. S. Chon, K. Sung and L. Yu, "The International Hospitality Business: Management and Operations," Routledge, New York, 1999.

[32] C. Lashley and D. Lee-Ross, "Organization Behavior for Leisure Services," Elsevier/Butterworth-Heinemann, Oxford, 2003.

[33] N. J. Allen and J. P. Meyer, "The Measurement and An- tecedents of Affective, Continuance and Normative Commitment to the Organization," Journal of Occupational Psychology, Vol. 63, No. 4, 1990, pp. 1-18. doi:10.1111/j.2044-8325.1990.tb00506.x

[34] D. Elizur, I. Borg, R. Hunt and I. M. Beck, "The Structure of Work Values: A Cross-Cultural Comparison," Journal of Organizational Behavior, Vol. 12, No. 1, 1991, pp. 2138. doi:10.1002/job.4030120103

[35] T. Redman and A. Wilkinson, "Contemporary Human Resource Management: Text and Cases," Pearson/Prentice Hall, Harlow, 2001.

[36] M. Krausz, A. Sagie and Y. Bidermann, "Actual and Preferred Work Schedules and Scheduling Control as Determinants of Job-Related Attitudes," Journal of Vocational Behavior, Vol. 56, No. 1, 2000, pp. 1-11. doi:10.1006/jvbe.1999.1688

[37] R. R. Sinclair, J. E. Martin and R. P. Michel, "Full-Time and Part-Time Subgroup Differences in Job Attitudes and Demographic Characteristics," Journal of Organizational Behavior, Vol. 55, No. 3, 1999, pp. 337-357.

[38] T. N. Martin and J. C. Hafer, "The Multiplicative Interaction Effects of Job Involvement and Organizational Commitment on the Turnover Intentions of Full-Time and Part-Time Employees," Journal of Vocational Behavior, Vol. 46, No. 3, 1995, pp. 310-331. doi:10.1006/jvbe.1995.1023

[39] M. Easterby, R. Thorp and A. Lowe, "Management Research," 3rd Edition, Sage, New York, 2008. 


\section{Appendix}

Table A1. Descriptive statistics for a job attitude.

\begin{tabular}{ccc}
\hline & Mean & Standard deviation \\
\hline Job attitude & 113.20 & 14.30 \\
Job environment & 32.12 & 6.30 \\
Remuneration & 23.10 & 4.80 \\
Administration & 27.20 & 5.30 \\
Job progress & 24.35 & 4.22 \\
Colleagues & 38.24 & 3.13 \\
\hline
\end{tabular}

Table A2. Descriptive statistics for employee commitment.

\begin{tabular}{ccc}
\hline & Mean & Standard deviation \\
\hline Affective commitment & 20.12 & 3.02 \\
Normative commitment & 22.41 & 5.02 \\
Continuance commitment & 17.02 & 7.41 \\
Organizational commitment & 55.43 & 9.24 \\
\hline
\end{tabular}

Table A3. Person correlation matrix for job attitude.

\begin{tabular}{ccc}
\hline \multicolumn{2}{c}{ Job attitude } \\
\hline & Pearson correlation & Sig (2-tailed) \\
\hline Job environment & 0.131 & 0.396 \\
Remuneration & 0.598 & $0.000^{* *}$ \\
Administration & 0.268 & $0.042^{*}$ \\
Job progress & 0.585 & $0.000^{* *}$ \\
Colleagues & 0.386 & $0.003^{* *}$ \\
\hline
\end{tabular}

Note: ${ }^{*} \mathrm{p}<0.05 ;{ }^{* *} \mathrm{p}<0.01$

Table A4. Person correlation between job attitude and biographical variables.

\begin{tabular}{cc}
\hline & Job attitude \\
\hline Sex & $0.67^{* *}$ \\
Age & $0.50^{* *}$ \\
Job status & $0.45^{* *}$ \\
Education level & $0.28^{*}$ \\
Job level & $0.37^{* *}$ \\
\hline
\end{tabular}

Note: ${ }^{*} \mathrm{p}<0.05 ;{ }^{* *} \mathrm{p}<0.01$
Table A5. Person correlation between job attitude and employee commitment.

\begin{tabular}{ccc}
\hline & \multicolumn{2}{c}{ Job attitude } \\
\hline & Pearson Correlation & Sig (2-tailed) \\
\hline Affective commitment & 0.342 & $0.021^{*}$ \\
Normative commitment & 0.436 & $0.002^{* *}$ \\
Continuance commitment & 0.701 & $0.000^{* *}$ \\
Organizational commitment & 0.472 & $0.000^{* *}$ \\
\hline
\end{tabular}

Note: ${ }^{*} \mathrm{p}<0.05 ;{ }^{* *} \mathrm{p}<0.01$.

Table A6. Person correlation between employee commitment and biographical variable.

\begin{tabular}{ccc}
\hline & Employee commitment \\
\hline & Pearson correlation & Sig (2-tailed) \\
\hline Sex & 0.720 & $0.00^{* *}$ \\
Age & 0.560 & $0.00^{* *}$ \\
Job status & 0.420 & $0.00^{* *}$ \\
Education level & 0.132 & 0.05 \\
Job level & 0.552 & $0.00^{* *}$ \\
\hline
\end{tabular}

Note: ${ }^{*} \mathrm{p}<0.05 ;{ }^{* *} \mathrm{p}<0.01$.

Table A7. Multiple regression results: Job attitude and biographical variables.

\begin{tabular}{cccc}
\hline Multiple R & 0.602 & & \\
R Square & 0.361 & & \\
Adjusted R square & 0.332 & & \\
Standard error & 12.961 & & \\
F & 5.295 & & Sig T \\
Sig F & $0.00^{* *}$ & & $0.03969^{*}$ \\
Variable & Beta & $\mathrm{T}$ & $0.0108^{*}$ \\
Age & -0.2164 & -0.2670 & $0.0029^{* *}$ \\
Sex & -0.2684 & -2.4021 & 0.0701 \\
Job status & -0.3189 & -3.0942 & $0.0229^{*}$ \\
Education level & -0.1537 & -1.2951 & \\
Job level & -0.1806 & -1.1092 & \\
\hline
\end{tabular}

Note: ${ }^{*} \mathrm{p}<0.05 ;{ }^{* *} \mathrm{p}<0.01$ 
Table A8. ANOVA analysis results: Job attitude and biographical variables.

\begin{tabular}{cccccc}
\hline \multicolumn{5}{c}{ ANOVA-Analysis of Variance } \\
\hline \multicolumn{5}{c}{ Alpha 0.05} & \multicolumn{2}{c}{ F-table 3.874} & & \\
\multicolumn{2}{c}{ ANOVA Table } & & & & \\
Sources & SS & df & MS & F-stat & p-value \\
Between & 138 & 4 & 68.7 & 5.295 & 0.04274 \\
Error & 192.5 & 12 & 18.3 & & \\
Total error & 330.5 & 16 & & & \\
\hline
\end{tabular}

Table A10. ANOVA analysis result: Employee commitment and biographical variables.

\begin{tabular}{|c|c|c|c|c|c|}
\hline \multicolumn{6}{|c|}{ ANOVA-Analysis of Variance } \\
\hline \multicolumn{2}{|c|}{ Alpha 0.05} & \multicolumn{2}{|c|}{ F-table 3.874} & & \\
\hline \multicolumn{6}{|c|}{ ANOVA Table } \\
\hline Sources & SS & $\mathrm{df}$ & MS & F-stat & $\mathrm{p}$-value \\
\hline Between & 144 & 4 & 72.6 & 5.357 & 0.04571 \\
\hline Error & 196.5 & 12 & 16.8 & & \\
\hline Total error & 340.5 & 16 & & & \\
\hline
\end{tabular}

Table A9. Multiple regression results: Employee commitment and biographical variables.

\begin{tabular}{cccc}
\hline Multiple R & 0.622 & & \\
R Square & 0.390 & & \\
Adjusted R square & 0.323 & & \\
Standard error & 0.409 & & \\
F & 5.357 & & Sig T \\
Sig F & $0.00^{* *}$ & & $0.0039^{* *}$ \\
Variable & Beta & $\mathrm{T}$ & $0.0000^{* *}$ \\
Age & -0.2793 & -2.7052 & $0.0000^{* *}$ \\
Sex & -0.3522 & -3.1921 & 0.5302 \\
Job status & -0.4692 & -4.3042 & $0.0020^{* *}$ \\
Education level & -0.1002 & -0.9832 & \\
Job level & 0.1192 & -1.2042 & \\
\hline
\end{tabular}

Note: ${ }^{*} \mathrm{p}<0.05 ;{ }^{* *} \mathrm{p}<0.01$ 